Bogomaz, O., Shulha, M., Kotov, D., Koloskov, A., Zalizovski, A. (2020).

An artificial neural network for analysis of ionograms obtained

by ionosonde at the Ukrainian Antarctic Akademik Vernadsky station.

Ukrainian Antarctic Journal, 2, 59-67.

https://doi.org/10.33275/1727-7485.2.2020.653

\author{
O. Bogomaz 1, 2, *, M. Shulha ${ }^{1,2}$, D. Kotov ${ }^{1,2}$, A. Koloskov ${ }^{3,2}$, A. Zalizovski ${ }^{3,2,4}$ \\ ${ }^{1}$ Institute of Ionosphere of the National Academy of Sciences of Ukraine, \\ Kharkiv, 61001, Ukraine \\ ${ }^{2}$ State Institution National Antarctic Scientific Center, Ministry of Education \\ and Science of Ukraine, Kyiv, 01601, Ukraine \\ ${ }^{3}$ Institute of Radio Astronomy of the National Academy of Sciences of Ukraine, \\ Kharkiv, 61002, Ukraine \\ ${ }^{4}$ Space Research Centre of Polish Academy of Sciences, Warsaw, 00-716, Poland \\ *Corresponding author: o.v.bogomaz1985@gmail.com
}

\title{
An artificial neural network for analysis of ionograms obtained by ionosonde at the Ukrainian Antarctic Akademik Vernadsky station
}

\begin{abstract}
The article presents the developed artificial neural network for F2 ionosphere layer traces scaling on ionograms obtained using the IPS-42 ionosonde installed at the Ukrainian Antarctic Akademik Vernadsky station. The parameters of the IPS-42 ionosonde and the features of the data obtained with it, in particular the format of the output files, are presented. The advantages of using an artificial neural network for identification of traces on ionograms are demonstrated. Usually, an automatic scaling of the ionograms requires a lot of machine time however implementation of an artificial neural network speeds up computations significantly allowing to process incoming ionograms even in the real time mode. The choice of architecture of an artificial neural network is substantiated. The U-Net architecture was chosen. The method of creating and training the neural network is described. The artificial neural network development process included choosing the number of layers, types of activation functions, optimization method and input layer size. Software developed was written in Python programming language with use of the Keras library. Examples of data used for training of the artificial neural network are shown. The results of testing an artificial neural network are presented. The data obtained with the artificial neural network are compared with the results of manual processing of ionograms. Data for training the artificial neural network were obtained in March, 2017 using the IPS-42 ionosonde installed at the Ukrainian Antarctic Akademik Vernadsky station; data for testing were obtained in 2017 and 2020. The developed artificial neural network has minor flaws but they are easily eliminated by retraining the network on a more representative dataset (obtained in various years and seasons). The general results of testing indicate good prospects in further developing this artificial neural network and software for working with it.
\end{abstract}

Keywords: critical frequency, deep learning, electron density, ionosphere, pattern recognition

\section{Introduction}

Vertical sounding of the Earth's ionosphere is the main remote sensing method to study its structure. The sounding is carried out by means of ionosondes that are radar systems working mostly with steppedfrequency signals. The dependence of virtual height of reflected signal on carrier frequency (represented as plot called ionogram) shows the distribution of the ionospheric plasma frequencies by height. Combined with a valid model of the ionosphere, a correct scaling of the ionogram, which consists in accurate recognition of the F2, F1 and E layers, allows one to reconstruct the height profile of the electron density in 
the ionosphere. Ionogram interpretation could be provided according to (Piggott \& Rawer, 1972; Wakai et al., 1987), a program IonogramViewer2 for manual scaling is presented in (Bogomaz et al., 2019a), a program NHPC for reconstruction of electron density profiles is described in (Huang \& Reinisch, 1996). An approach to reconstruction of height profiles of electron density based on listed methods and software was recently tested by incoherent scatter technique (Bogomaz et al., 2019b) and its correctness was confirmed.

The operators trusted with ionogram interpretation have a wealth of experience working with such kind of data; yet the process still takes a lot of time, which is a significant practical constraint (Jeong et al., 2018). Whenever there is a need to quickly analyze copious data, there arises a question of automating the procedure. Currently, there are but a few software products for automatic ionogram scaling, and the most widely used of them are ARTIST (Galkin \& Reinisch, 2008) and Autoscala (Pezzopane \& Scotto, 2007). The programs are applicable only to a very narrow variety of ionosonde models (Bullett et al., 2010; Pezzopane et al., 2010; Reinisch \& Galkin, 2011).

We have developed software to automatically interpret data of the ionosonde installed at the Ukrainian Antarctic Akademik Vernadsky station (Akademik Vernadsky station). The program uses an artificial neural network (ANN) which identifies the trace of F2 layer on the ionogram. This approach was chosen because the automatic interpretation of the ionograms is computationally hard, and ANNs have achieved some success in image recognition tasks, including ionogram automatic scaling (Xiao et al., 2020). Moreover, further incorporation of recognizing traces of the F1 and $\mathrm{E}$ layers would need only training the network on other data sets. The program would allow to process the large amount of data of ionosonde at the Akademik Vernadsky station accumulated over many years and also to scale incoming ionograms in real time.

\section{Equipment, data and methods}

Equipment. The Akademik Vernadsky station ( $65^{\circ} 15^{\prime} \mathrm{S}$, $64^{\circ} 15^{\prime} \mathrm{W}$ ) has the IPS-42 ionosonde. This is unique scientific equipment developed and manufactured in Australia (Broom, 1984). The transmitter pulse pow- er output is $5 \mathrm{~kW}$, pulse width is $\sim 40 \mu \mathrm{s}$. The sounding frequency is sweeping in the range of $1.0-22.6 \mathrm{MHz}$ (576 logarithmically spaced values). The range of the virtual heights is $0-800 \mathrm{~km}$ (512 values). The ionogram registration rate is one per 15 minutes. Obtaining ionograms in digital form was implemented in 2001 (Koloskov et al., 2019; Zalizovski et al., 2020).

Data. Every ionogram is stored in a binary file. The number of heights and the number of sounding frequencies determine the image size of 576 columns by 512 rows. Every pixel is represented by 1 bit (i.e. the image is bitonal). Also, 64 bytes are allocated for file header, but it is not used. Therefore, the ionogram file is fixed-size of $576 \times 512 / 8+64=36928$ bytes. The date and time of ionogram registration are embedded directly into the image as year without century, day number of the year and local time LT $=$ $=\mathrm{UTC}-4$. There are markers at 1.0, 1.4, 2.0, 2.8, $4.0,5.7,8.0,11.3,16.0$ and $22.6 \mathrm{MHz}$ on $\mathrm{x}$-axis of an ionogram as well as markers at $0,100,200,300,400$, $500,600,700$ and $800 \mathrm{~km}$ on $\mathrm{y}$-axis. The axes and the markers are also embedded into the image.

The images for training and testing the developed ANN were prepared in the GNU Image Manipulation Program (GIMP), a free and open-source raster graphics editor (https://www.gimp.org/). Raw ionograms in proprietary format were converted to portable network graphics (PNG) files. Afterwards, the ionogram set aside for training the ANN were manually edited to remove all information except traces of an ordinary component of the radio wave reflected from the F2 layer of the ionosphere. The ionograms for testing the ANN were left unchanged.

The training dataset included 31 ionograms obtained by the IPS-42 ionosonde at the Akademik Vernadsky station on March 17, 2017. Complete daily set of onehour apart data and several additional daytime and nighttime ionograms were used. For the testing dataset 24 ionograms obtained on the following day, March 18, one hour apart were taken. Some ionograms from the training dataset are shown on Fig. 1.

ANN development. Identifying traces on an ionograms is a specific case of image classification. Evidently, simple ANNs such as the perceptron or a fully connected neural network are not applicable to a task 


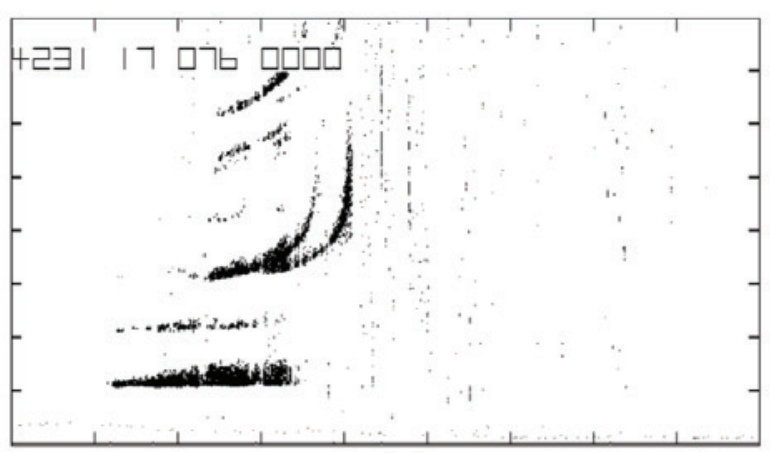

(a)

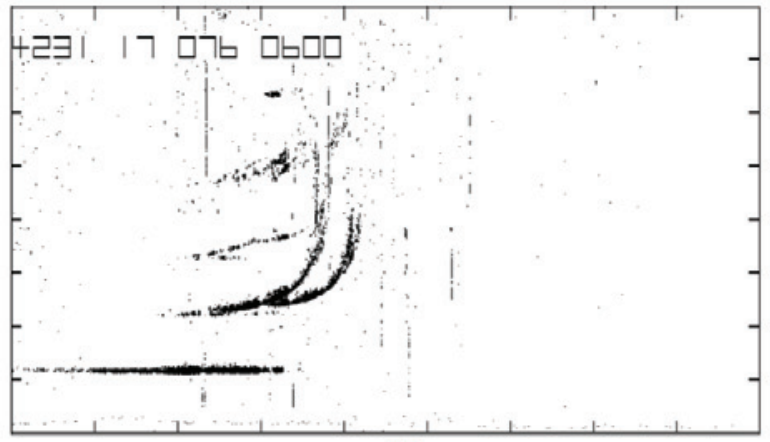

(b)

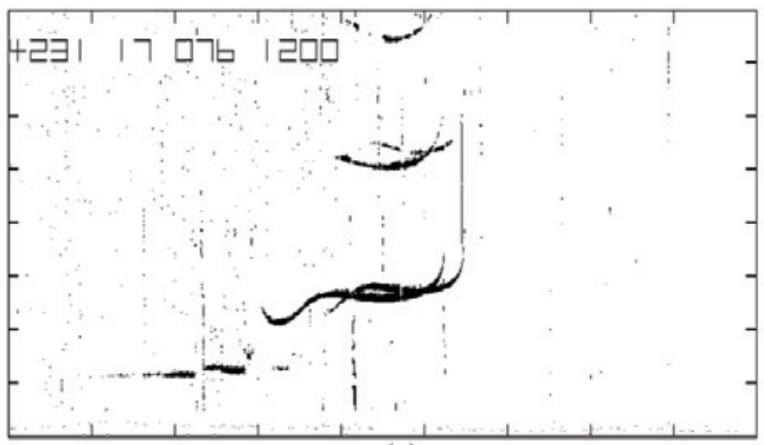

(c)

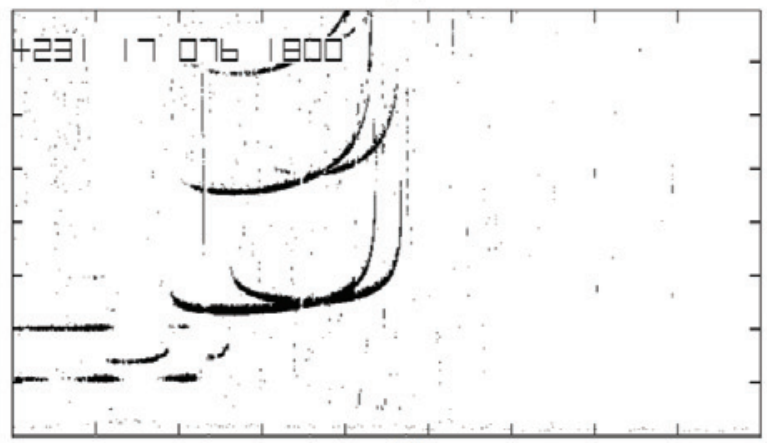

(d)

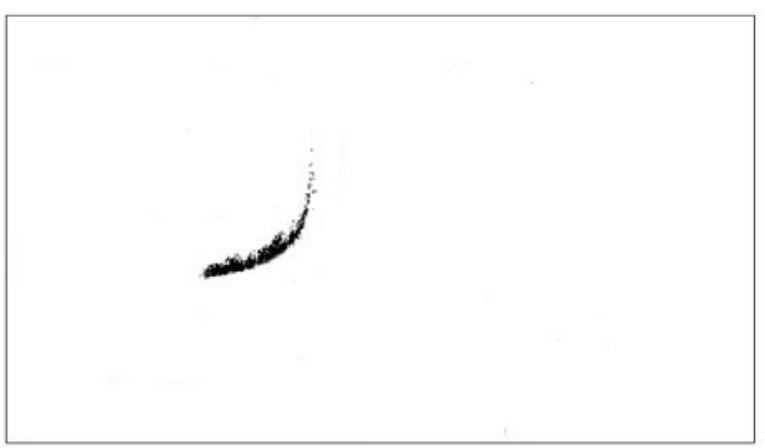

(e)

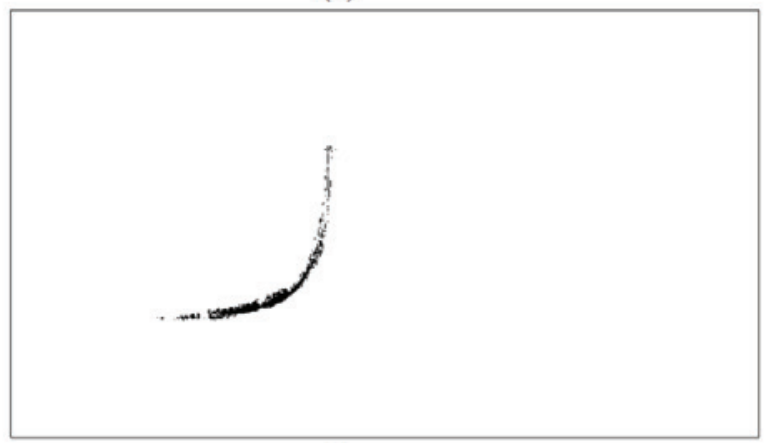

(f)

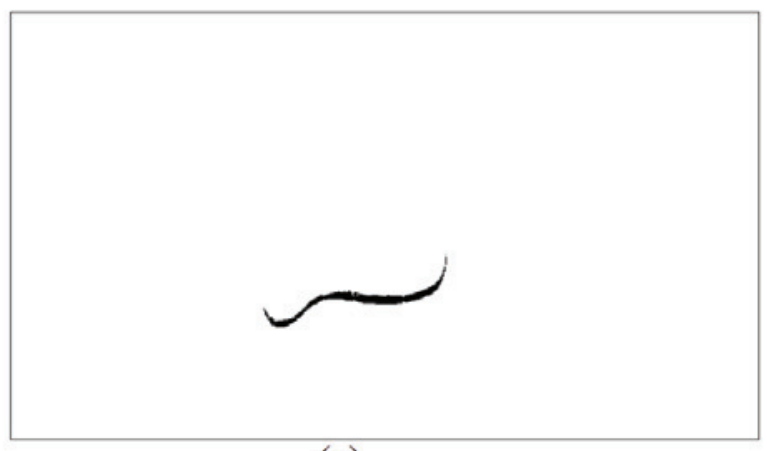

(g)

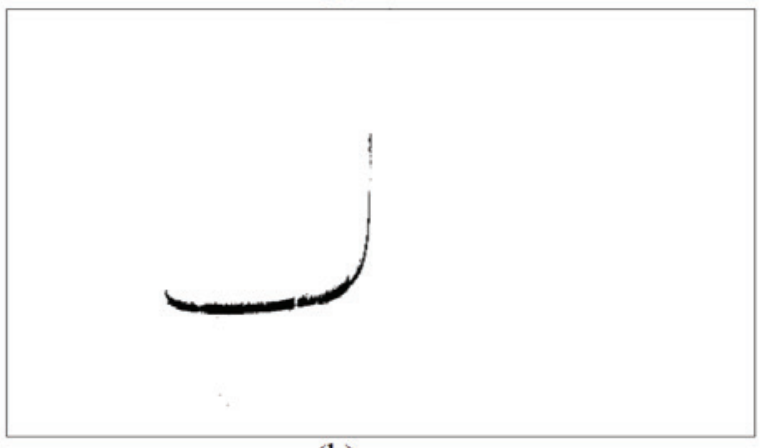

(h)

Figure 1. Prepared images for training the ANN: ionograms obtained on 17.03.2017 at 00:00, 06:00, 12:00 and 18:00 LT (a, b, c, d); masks with F2 layer traces (e, f, g, h) 


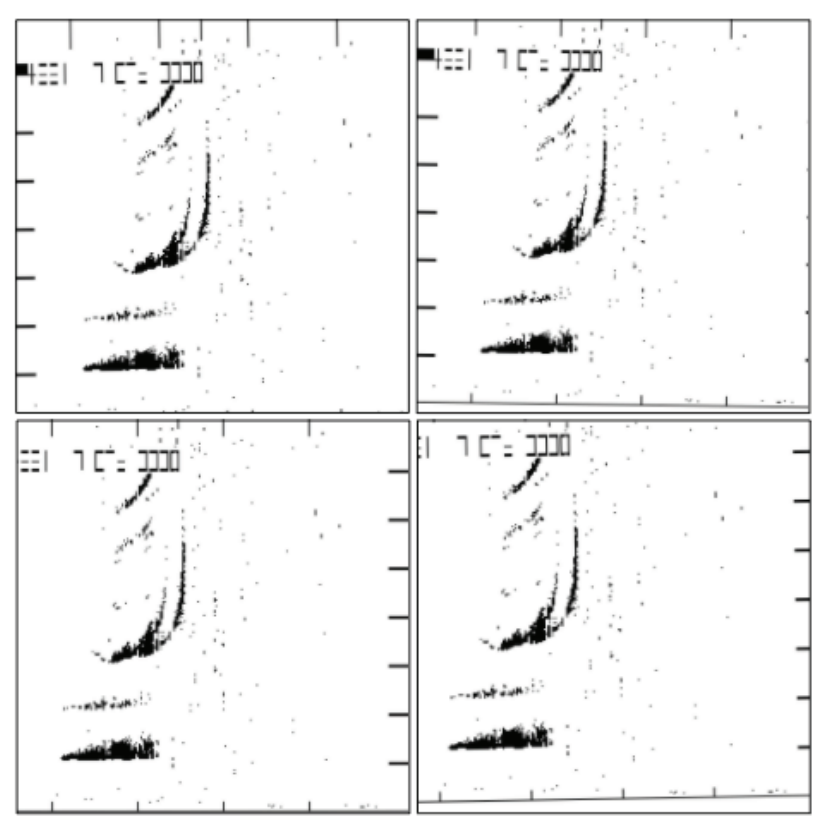

Figure 2. Examples of images generated from the ionogram obtained on 17.03.2017 at 00:00 LT used for ANN training

of such complexity. Thus, the search for the most suitable ANN targeted convolutional neural networks, especially the U-Net architecture developed for segmentation of biomedical images (Ronneberger et al., 2015). This ANN architecture did well in other cases such as forest type classification (Wagner et al., 2019) and road identification (Zhang et al., 2018; Yang et al., 2019) on aerial pictures. The paper by (Mochalov \& Mochalova, 2019) describes a U-Net architecture ANN used to interpret ionograms of the ionosonde "Parus-A" operated at the Institute of Cosmophysical Research and Radio Wave Propagation (Kazan, Russia) since August 2015.

Table. Characteristics of computer where ANN was developed

\begin{tabular}{|l|l|}
\hline \multicolumn{1}{|c|}{ Characteristic } & \multicolumn{1}{c|}{ Value } \\
\hline CPU & AMD Athlon 200GE \\
CPU frequency & $3.2 \mathrm{GHz}$ \\
Cores/threads number & $2 / 4$ \\
RAM & 4 Gbytes \\
SSD & 120 Gbytes \\
Operating system, architecture & Windows 10, 64-bit \\
\hline
\end{tabular}

ANN development process includes choosing the number of layers, types of activation functions, optimization method and input image size.

Input image size should be sufficient to highlight important features, e.g. the F2 layer trace. On the other hand, the image size is limited by the available memory and training time. ANN can work either on multiple graphics processing unit (GPU) cores or central processing unit (CPU). Because the ANN was trained on the CPU, the input layer was lesser than an ionogram. Chosen input layer size was $256 \times 256$ (for an ANN with the U-Net architecture it is advisable to use input layers with sizes being powers of two). We also evaluated the ANN layers needed to execute the search for trace on the ionograms as no less than 9 .

As activation functions we chose ReLU one (rectified linear unit, an analog of the half wave rectifier in electronics) and the sigmoid. The ReLU function allows to train deep neural networks faster and more efficiently on large and complex data sets, yet there can appear the dead activation states problem: the neurons can become inactive for all input values. In this state, the gradient flowing through the neuron is zero, so it cannot recover and "dies". The problem usually occurs at very high learning rate.

Among the available optimizers (SGD, RMSprop, Adagrad, Adadelta, Adam, Adamax, Nadam) we chose Adam (Bushaev, 2018). It allows alleviating such optimization algorithm problems as convergence to local minima and inability to recognize rare features. The optimizer has also adaptive settings for the optimal learning rate.

The software was written in Python (https://www. python.org/), the ANN was realized using the Keras library (https://keras.io/). Classes and functions for work with models were downloaded from the keras. models package, for ANN layers - from the keras. layers, for optimizers - from keras.optimizers package. During the training we used an instance of the Image DataGenerator class imported from the keras. preprocessing.image package, which allows to procure a dataset much larger than the initial one consisting of a few manually edited images. It is achieved by such manipulations as rotation, zoom, shear, shift and flip. Parameters of image modification are set by the param- 
eter of the constructor. Maximal rotation angle was set to $1^{\circ}$, maximal shear, zoom, and shift were set to $5 \%$ and no flip was selected. Thus, 31 ionograms prepared for ANN training yielded 2909 images. An example of four generated images is presented on Fig. 2 .

Downscaling and upscaling images from $576 \times 512$ to $256 \times 256$ and vice versa were done using the resize function from the skimage.transform package of the scikit-image library (https://scikit-image.org/).

The ANN was stored as HDF5 file (https://www. hdfgroup.org/solutions/hdf5/).

\section{Results and Discussion}

ANN training and testing using prepared images was done by a personal computer with parameters described in the Table. It should be noted that it is recommended to use NVidia video adapters since their GPUs are supported by the parallel computing platform CUDA (https://developer.nvidia.com/cudazone). However, if this solution is unavailable, it is possible to use CPUs support the Advanced Vector Extensions (AVX) instructions. ANN training on a computer with these characteristics (AMD Athlon 200GE CPU supports AVX as well as AVX2) took approximately 5 hours. In comparison, the ANN of (Mochalov \& Mochalova, 2019) was trained on an NVidia Tesla K80 video adapter during approximately 3 hours. The ANN of (Ronneberger et al., 2015) for segmentation of biomedical images was done on an NVidia Titan video adapter over 10 hours.

As a result, a trained ANN (a Keras model with model weights) was saved to file of about 355 Mbytes.

The loss and accuracy parameters which characterize how well an ANN recognizes images were, after 300 epochs, 0.0051 and 0.9994 , respectively.

Some of the ANN testing results is provided on Fig. 3. It can be seen that the ANN can well identify traces obtained by the ordinary component of the radio wave being reflected by the F2 ionosphere layer.

Further ANN testing on data obtained in various years and seasons revealed such disadvantages:

1) Sometimes, the ANN additionally marks multiple reflections from the ionosphere, which are the result of the sounding pulse being reflected by ionosphere, then by ground and finally the ionosphere again.
2) Sometimes the ANN records a part of the trace created by an extraordinary wave.

3) Due to insufficient training dataset, recognizing traces above $4 \mathrm{MHz}$ is complicated.

The above-mentioned issues could be easily resolved by adding such problematic ionograms to the training dataset and retraining the ANN again.

An example of comparison of the ANN interpreting traces of the F2 layer with results obtained by an operator working with IonogramViewer2 software (https://github.com/Albom/IonogramViewer2) is shown on Fig. 4. The ANN needs several seconds to process one ionogram that is much faster than manual scaling.

To identify traces of the $\mathrm{F} 1$ and $\mathrm{E}$ layers it is possible either to train additionally two more independent ANN on independent training datasets and then identify each layer sequentially, as in (Mochalov \& Mochalova, 2019), or to color-code each layer in a training dataset. Then the task of multi-class semantic segmentation will be provided directly by the only ANN.

\section{Conclusions}

There was developed an ANN to identify traces of the F2 layer on ionograms obtained by the IPS-42 ionosonde of the Ukrainian Antarctic Akademik Vernadsky station. Similar ANN trained on relevant datasets can be applied to identify traces of $\mathrm{F} 1$ and $\mathrm{E}$ layers. The developed ANN is not without flaws. It can mistakenly mark multiple reflections from the ionosphere and traces of the $\mathrm{x}$-component of the radio wave and it does not reliably process traces when critical frequency $f_{o} \mathrm{~F} 2$ is more than $4 \mathrm{MHz}$. However, these flaws might be easily eliminated by retraining the network on a more representative dataset. The ANN was tested on ionosonde data obtained in 2017 and 2020. The results demonstrate good prospects in further developing the network and the relevant software, especially as to the evaluation of the critical frequencies of the ionosphere layers, necessary to reconstruct electron density profiles.

Author contributions. The idea, realization, writing and illustration preparing: OB. Data acquisition and preparation: AK and AZ. Data processing: MS. Man- 


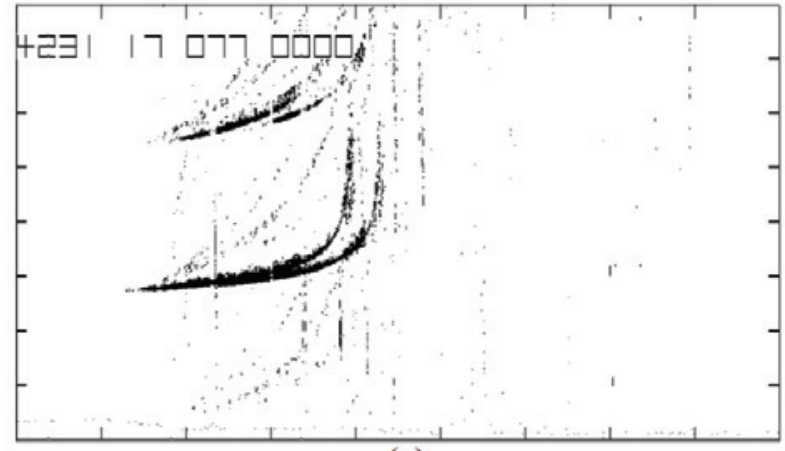

(a)

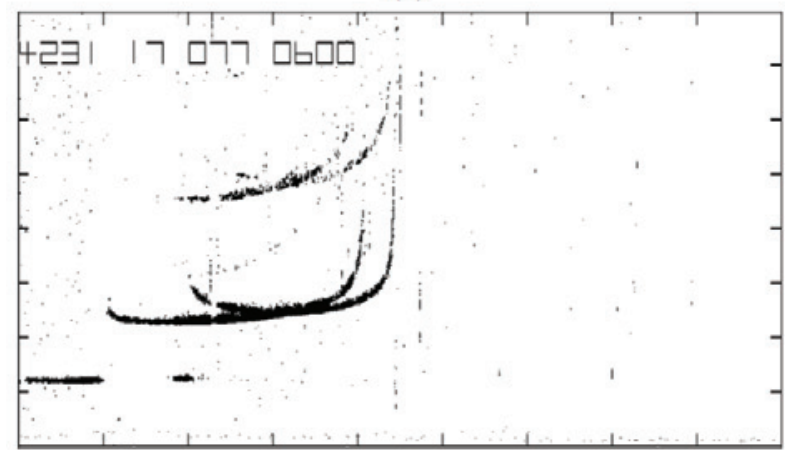

(b)

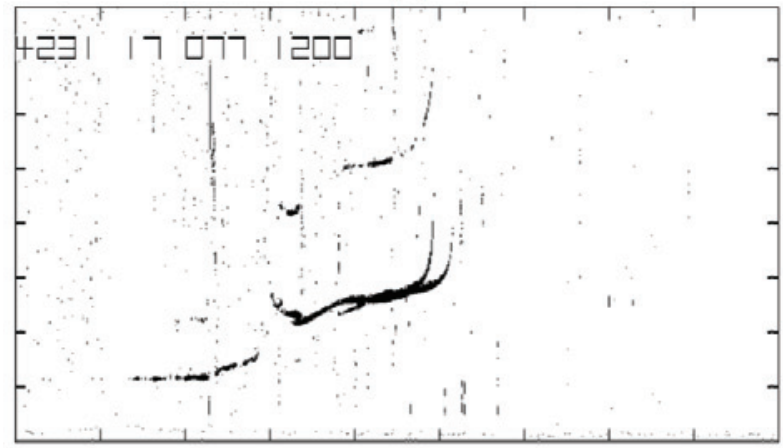

(c)

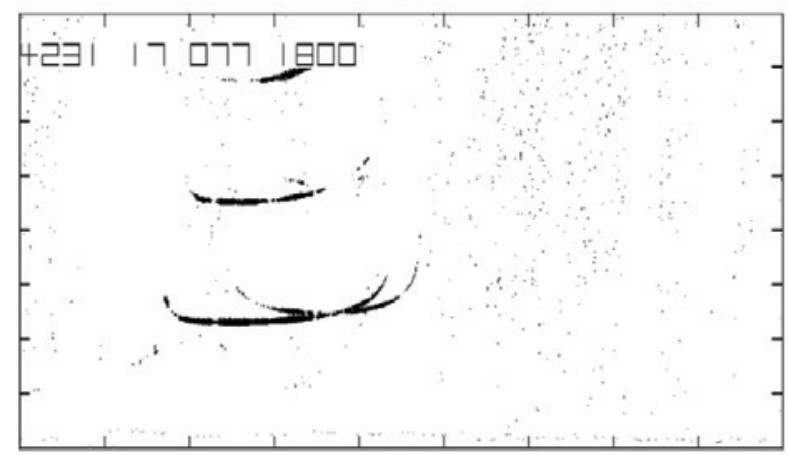

(d)

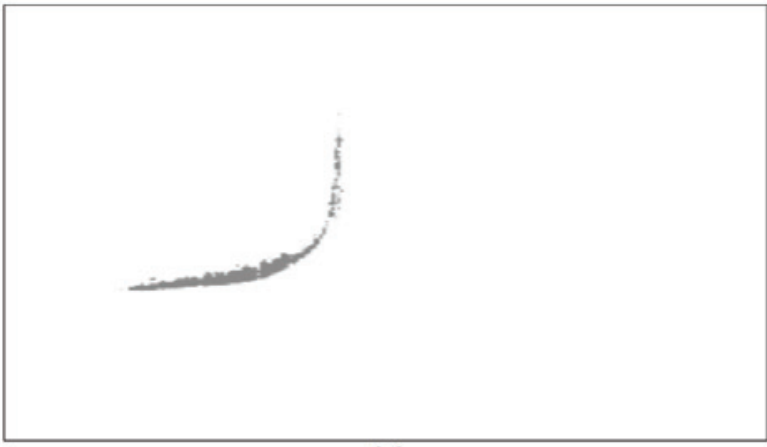

(e)

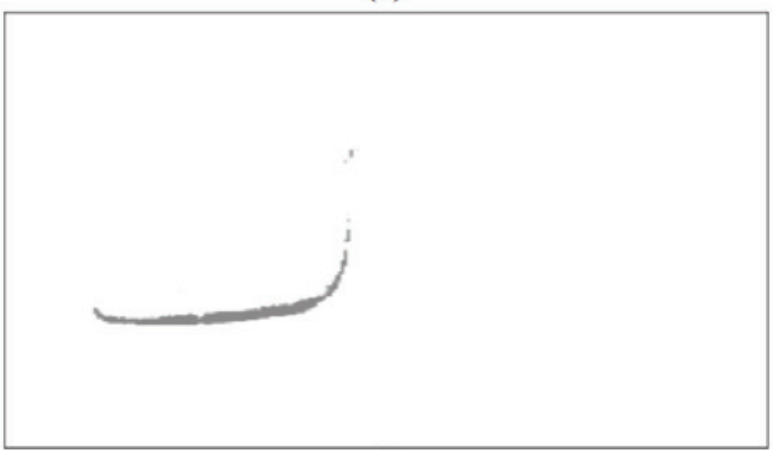

(f)

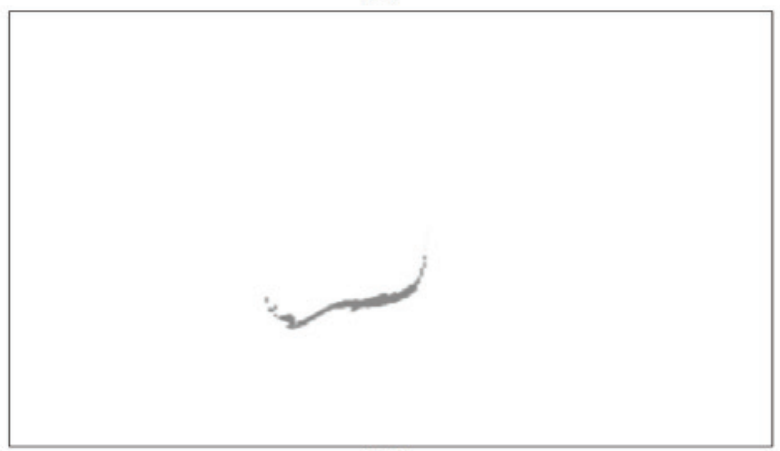

(g)

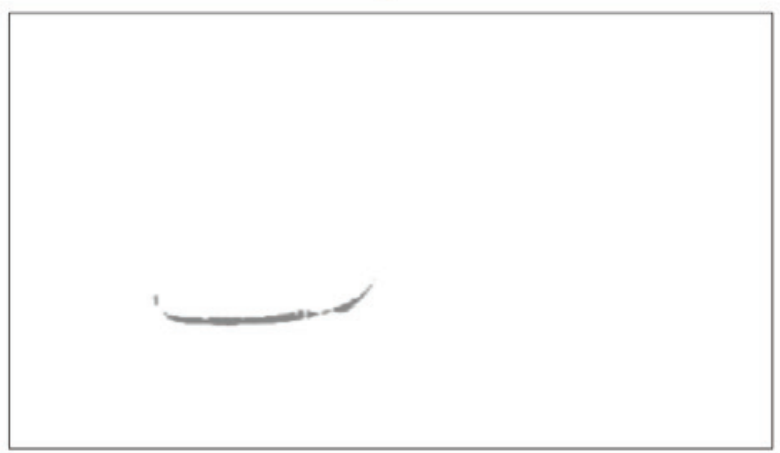

(h)

Figure 3. Ionograms from a testing dataset obtained on 18.03.2017 at 00:00, 06:00, 12:00, and 18:00 LT (a, b, c, d) and the results of F2 layer scaling using the developed ANN (e, f, g, h) 


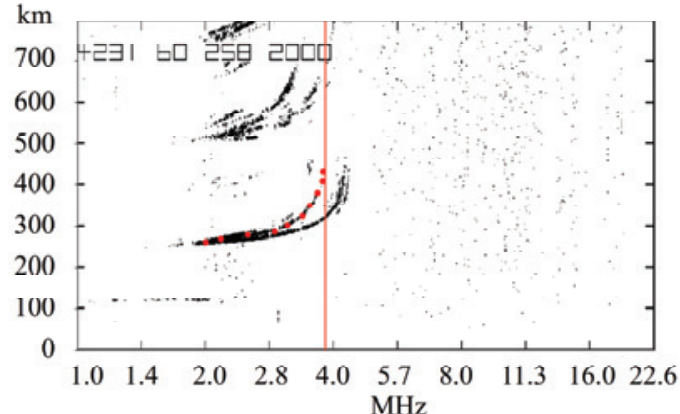

(a)

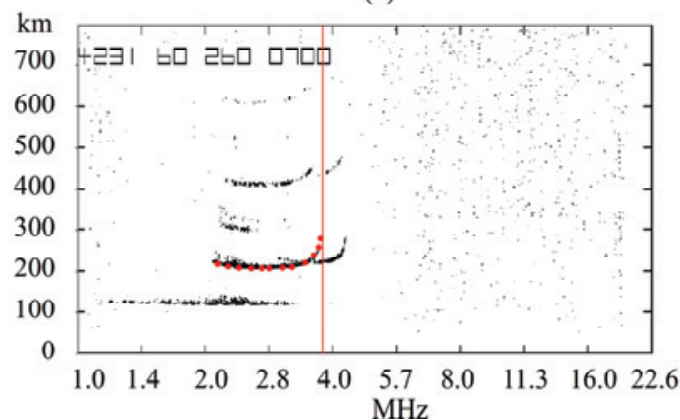

(b)

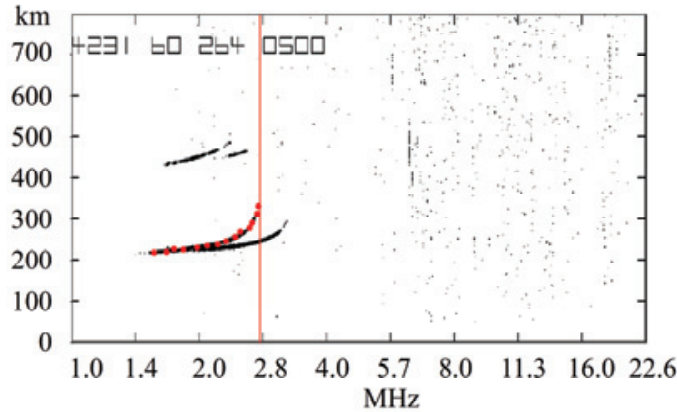

(c)

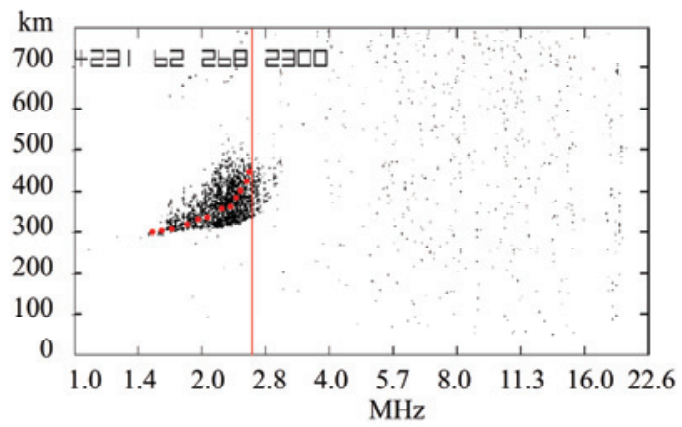

(d)

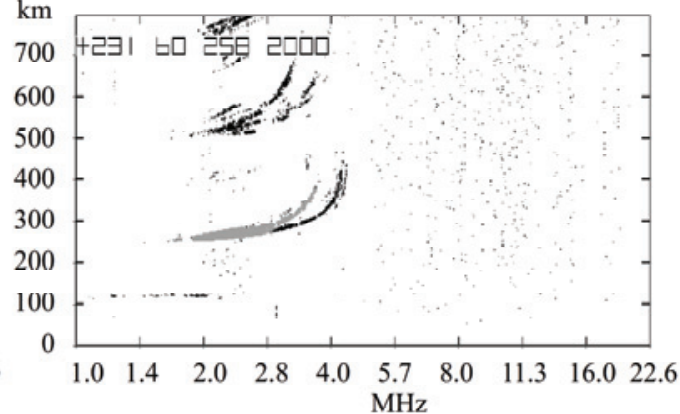

(e)

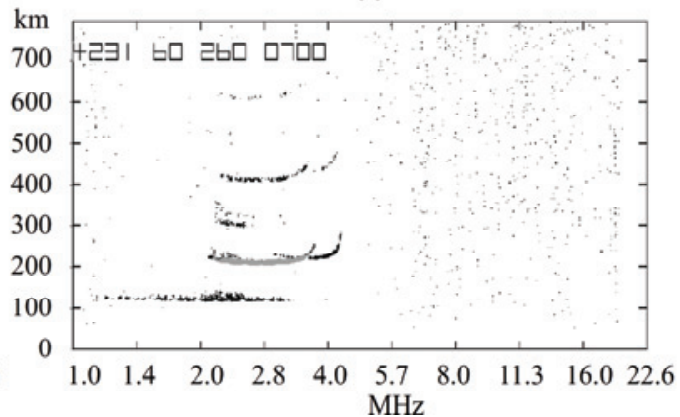

(f)

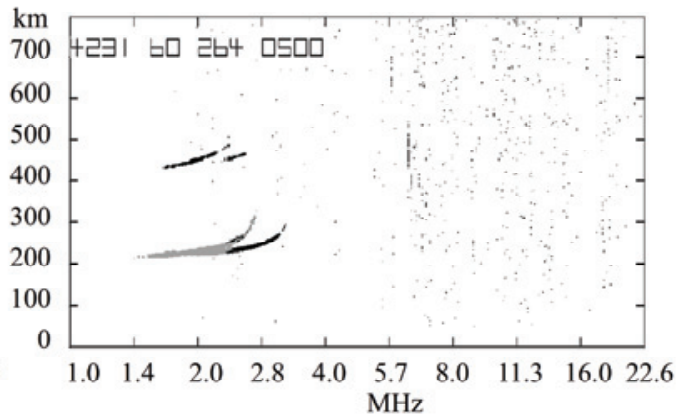

(g)

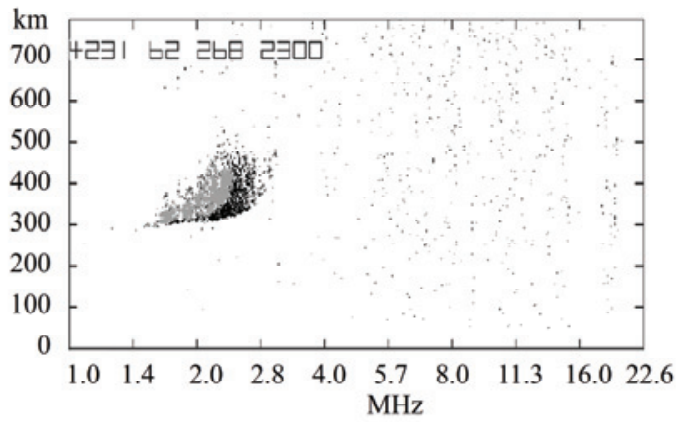

(h)

Figure 4. Comparison of the results of manual scaling of $F 2$ layer traces ( $a, b, c, d)$ with the results obtained using ANN (e, f, g, h). Dots on the left panel are the traces points; vertical lines show critical frequencies of $\mathrm{F} 2$ ionosphere layer $f_{0} \mathrm{~F} 2$. On the right panel, the traces predicted by the ANN are marked gray. Ionograms were obtained on 14.09.2020 at 20:00 LT (a, e), 16.09.2020 at 07:00 LT (b, f), 20.09.2020 at 05:00 LT (c, g), and 22.09.2020 at 23:00 LT (d, h) 
uscript review and editing: DK, AK, and AZ. All authors have read and agree to publish the current version of the manuscript.

Conflict of Interest. The authors declare no conflict of interests.

Funding. The study was done in the framework of the grant proposals "Investigation of the ionosphereplasmasphere system over Antarctica and Ukraine during the periods with quiet space weather conditions" (\#0120U104549) and "Investigation of processes in the Earth-ionosphere cavity according to the data of broadband electromagnetic monitoring at the Antarctic station Akademik Vernadsky" (\#0120U104223) financed by the State Institution National Antarctic Scientific Center, Ministry of Education and Science of Ukraine in 2020.

\section{References}

Bogomaz, O. V., Kotov, D. V., Shulha, M. O., \& Gorobets, M. V. (2019b). Comparison of the F2 layer peak height variations obtained by ionosonde and incoherent scatter radar. Bulletin of the National Technical University "KhPI", 25(1350), 58-61. Retrieved November 3, 2020, from http://iion.org.ua/ article/bulletin-25/

Bogomaz, O. V., Shulha, M. O., Kotov, D. V., Zhivolup, T. G., Koloskov, A. V., Zalizovski, A. V., Kashcheyev, S. B., Reznychenko, A. I., Hairston, M. R., \& Truhlik, V. (2019a). Ionosphere over Ukrainian Antarctic Akademik Vernadsky station under minima of solar and magnetic activities, and daily insolation: case study for June 2019. Ukrainian Antarctic Journal, 2(19), 84-93. https://doi.org/10.33275/1727-7485.2(19).2019.154

Broom, S. M. (1984). A new ionosonde for Argentine Islands ionospheric observatory, Faraday Station. British Antarctic Survey Bulletin, 62, 1-6. Retrieved November 3, 2020, from http://nora.nerc.ac.uk/id/eprint/523821/

Bullett, T., Malagnini, A., Pezzopane, M., \& Scotto, C. (2010). Application of Autoscala to ionograms recorded by the VIPIR ionosonde. Advances in Space Research, 45(9), 1156-1172. https://doi.org/10.1016/j.asr.2010.01.024

Bushaev, V. (2018). Adam - latest trends in deep learning optimization. Towards Data Science. https://towardsdatascience. com/adam-latest-trends-in-deep-learning-optimization-6be9a291375c

Galkin, I. A., \& Reinisch, B. W. (2008). The new ARTIST 5 for all digisondes. Ionosonde Network Advisory Group Bulletin, 69(8), 1-8. http://www.sws.bom.gov.au/IPSHosted/INAG/ web-69/2008/artist5-inag.pdf

Huang, X., \& Reinisch, B. W. (1996). Vertical electron density profiles from the Digisonde network. Advances in Space
Research, 18(6), 121-129. https://doi.org/10.1016/0273-1177 (95)00912-4

Jeong, S. H., Kim, Y. H., Kim, K. N. (2018). Manual scaling of ionograms measured at Jeju $\left(33.4^{\circ} \mathrm{N}, 126.3^{\circ} \mathrm{E}\right)$ throughout 2012. Journal of Astronomy and Space Sciences, 35(3), 143149. https://doi.org/10.5140/JASS.2018.35.3.143

Koloskov, O. V., Kashcheyev, A. S., Zalizovski, A. V., Kashcheyev, S. B., Budanov, O. V., Charkina, O. V., Pikulik, I. I., Lysachenko, V. M., Sopin, A. O., Reznychenko, A. I. (2019). New digital ionosonde developed for Akademik Vernadsky station. In IX International Antarctic Conference dedicated to the 60th anniversary of the signing of the Antarctic Treaty in the name of peace and development of international cooperation, 14-16 May 2019, Kyiv, Ukraine (pp. 170-171). Retrieved November 3, 2020, from http://uac.gov.ua/internationalcooperation/mak/mak-2019/

Mochalov, V., \& Mochalova, A. (2019). Application of Deep Learning to Recognize Ionograms. In 2019 Russian Open Conference on Radio Wave Propagation (RWP), 1-6 July 2019, Kazan, Russia (pp. 477-479). https://doi.org/10.1109/RWP. 2019.8810326

Pezzopane, M., \& Scotto, C. (2007). Automatic scaling of critical frequency foF2 and $M U F(3000) F 2$ : A comparison between Autoscala and ARTIST 4.5 on Rome data. Radio Science, 42(4), Article RS4003.

Pezzopane, M., Scotto, C., Tomasik, Ł., \& Krasheninnikov, I. (2010). Autoscala: an aid for different ionosondes. Acta Geophysica, 58, 513-526. https://doi.org/10.2478/s11600-0090038-1

Piggott, W. R., \& Rawer, K. (Eds.). (1972). URSI handbook of ionogram interpretation and reduction (2nd ed.). (Report UAG23, WDC-A for STP, NOAA). http://www.sws.bom.gov.au/ IPSHosted/INAG/uag_23a/UAG_23A_indexed.pdf

Reinisch, B. W., \& Galkin, I. A. (2011). Global ionospheric radio observatory (GIRO). Earth, Planets and Space, 63, 377381. https://doi.org/10.5047/eps.2011.03.001

Ronneberger, O., Fischer, P., \& Brox, T. (2015). U-Net: Convolutional Networks for Biomedical Image Segmentation. In N. Navab, J. Hornegger, W. Wells, \& A. Frangi (Eds), Medical Image Computing and Computer-Assisted Intervention MICCAI 2015. MICCAI 2015. Lecture Notes in Computer Science: Vol 9351 (pp. 234-241). Springer. https://doi.org/10. 1007/978-3-319-24574-4_28

Wagner, F. H., Sanchez, A., Tarabalka, Y., Lotte, R. G., Ferreira, M. P., Aidar, M. P. M., Gloor, E., Phillips, O. L., \& Aragão, L. E. O. C. (2019). Using the U-net convolutional network to map forest types and disturbance in the Atlantic rainforest with very high resolution images. Remote Sensing in Ecology and Conservation, 5(4), 360-375. https://doi.org/10. $1002 /$ rse2.111

Wakai, N., Ohyama, H., \& Koizumi, T. (1987). Manual of ionogram scaling. Radio Research Laboratory, Ministry of Posts and Telecommunications. http://www.ursi.org/files/Commission Websites/INAG/scaling/japanese_manual_v3.pdf 
Xiao, Z., Wang, J., Li, J., Zhao, B., Hu, L., \& Liu, L. (2020). Deep-learning for ionogram automatic scaling. Advances in Space Research, 66(4), 942-950. https://doi.org/ 10.1016/j.asr.2020.05.009

Yang, X., Li, X., Ye, Y., Lau, R. Y. K., Zhang, X., \& Huang, X. (2019). Road detection and centerline extraction via deep recurrent convolutional neural network u-net. IEEE Transactions on Geoscience and Remote Sensing, 57(9), 72097220. https://doi.org/10.1109/TGRS.2019.2912301

Zalizovski A., Koloskov O., Kashcheyev A., Kashcheyev S., Yampolski Y., \& Charkina O. (2020). Doppler vertical sounding of the ionosphere at the Akademik Vernadsky station. Ukrainian Antarctic Journal, 1, 56-68. https://doi.org/10.33275/17277485.1.2020.379

Zhang, Z., Liu, Q., \& Wang, Y. (2018). Road extraction by deep residual u-net. IEEE Geoscience and Remote Sensing Letters, 15(5), 749-753.https://doi.org/10.1109/LGRS.2018. 2802944

Received: 3 November 2020

Accepted: 22 December 2020

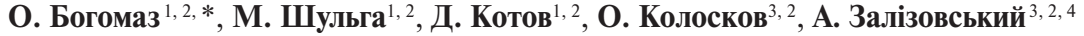 \\ ${ }^{1}$ Інститут іоносфери, м. Харків, 61001, Україна \\ 2 Державна установа Національний антарктичний науковий центр МОН України, \\ м. Київ, 01601, Україна \\ ${ }^{3}$ Радіоастрономічний інститут Національної академії наук України, м. Харків, 61002, Україна \\ ${ }^{4}$ Центр космічних досліджень Польської академії наук, м. Варшава, 00-716, Польща
}

*Автор для кореспонденції: o.v.bogomaz1985@gmail.com

Штучна нейронна мережа для аналізу іонограм, отриманих за допомогою іонозонду Української антарктичної станції «Академік Вернадський»

Реферат. У статті представлено розроблену штучну нейронну мережу для ідентифікації слідів шару F2 іоносфери на іонограмах, отриманих з використанням іонозонду IPS-42, встановленого на Українській антарктичній станції "Академік Вернадський". Наведено параметри іонозонду IPS-42 та особливості отриманих за його допомогою даних, зокрема формат вихідних файлів. Продемонстровано переваги використання штучної нейронної мережі для ідентифікації слідів на іонограмах. Зазвичай автоматичне масштабування іонограм потребує багато машинного часу, проте впровадження штучної нейронної мережі значно пришвидшує обчислення, дозволяючи обробляти вхідні іонограми навіть у режимі реального часу. Обгрунтовано вибір архітектури штучної нейронної мережі. Було обрано архітектуру U-Net. Описано методику створення та навчання нейронної мережі. Процес розробки штучної нейронної мережі включав вибір кількості шарів, типів активаційних функцій, методу оптимізації та розміру вхідного шару. Розроблене програмне забезпечення було написано на мові програмування Руthon із використанням бібліотеки Кеras. Наведено приклади даних, на яких проводилося навчання штучної нейронної мережі. Представлено результати тестування штучної нейронної мережі. Дані, отримані за допомогою штучної нейронної мережі, порівнюються з результатами ручної обробки іонограм. Дані для тренування штучної нейронної мережі були отримані за допомогою іонозонду IPS-42, що встановлено на Українській антарктичній станції "Академік Вернадський", у березні 2017 року; дані для тестування були отримані у 2017 та 2020 pр. Розроблена штучна нейронна мережа має незначні недоліки, але їх легко усунути шляхом повторного навчання мережі на більш репрезентативній виборці даних (отриманих у різні роки та сезони). Загальні результати тестування вказують на гарні перспективи подальшого розвитку цієї штучної нейронної мережі та програмного забезпечення, що працює з нею.

Ключові слова: глибинне навчання, іоносфера, концентрація електронів, критична частота, розпізнавання образів 